\title{
MIEJSKIE PARKI IMIENIA ADAMA WODZICZKI I WŁADYSŁAWA CZARNECKIEGO W POZNANIU
}

\author{
MUNICIPIAL PARKS NAMED AFTER ADAM WODZICZKO \\ AND WŁADYSEAW CZARNECKI IN POZNAŃ
}

\author{
Piotr Urbański, PaweŁ Piotr SzumigaŁa, PrzemysŁaw Tomczak, Sylwia Sosnowska, \\ Karolina SzUmigaŁa
}

\begin{abstract}
S. Sosnowska, Katedra Terenów Zieleni i Architektury Krajobrazu, Uniwersytet Przyrodniczy w Poznaniu, ul. Dąbrowskiego 159, 60-594 Poznań, Poland, e-mail: sylwia.sosnowska@up.poznan.pl

K. Szumigała, studentka Wydziału Architektury Politechniki Poznańskiej, ul. Nieszawska 13, 61-021 Poznań, Poland, e-mail: karolina.szumigala@wp.pl

P.P. Szumigała, Katedra Terenów Zieleni i Architektury Krajobrazu, Uniwersytet Przyrodniczy w Poznaniu, ul. Dąbrowskiego 159, 60-594 Poznań, Poland, e-mail: pawel.szumigala@up.poznan.pl

P. Tomczak, Katedra Terenów Zieleni i Architektury Krajobrazu, Uniwersytet Przyrodniczy w Poznaniu, ul. Dąbrowskiego 159, 60-594 Poznań, Poland, e-mail: przemyslaw.tomaczak@up.poznan.pl

P. Urbański, Katedra Terenów Zieleni i Architektury Krajobrazu, Uniwersytet Przyrodniczy w Poznaniu, ul. Dąbrowskiego 159, 60-594 Poznań, Poland, e-mail: piotr.urbanski@up.poznan.pl
\end{abstract}

(Received: October 10, 2018. Accepted: October 31, 2018)

\begin{abstract}
Aвstract. The article presents issues concerning selected, two city parks in Poznań, which are named after famous people - Prof. Adam Wodziczko and Prof. Władysław Czarnecki, distinguished in the protection of the greenery and landscape of the city of Poznan. The proof of the activity of both professors in the form of parks named after them requires constant efforts and investments in order tomaintain thesse areas of greenery condition. They are important elements of the city's landscape but also have cultural value.
\end{abstract}

KeY words: Adam Wodziczko, Władysław Czarnecki, park, Poznań

\section{WSTĘP}

Formą upamiętniania wybitnych twórców zasłużonych dla danej społeczności i nauki jest między innymi nadawanie parkom nazw pochodzących od imion i nazwisk tych ludzi. Poznań jest chlubnym przykładem takich działań. Osobami, które zostały uhonorowane w ten sposób przez społeczeństwo Poznania są między innymi profesorowie: Adam Wodziczko i Władysław Czarnecki. Parki ich imienia są zlokalizowane w dzielnicy Stare Miasto, w sąsiedztwie parku Cytadela w Poznaniu. Pierwszy jest położony przy alei Wielkopolskiej na Sołaczu, drugi przy Alejach
Solidarności na Winogradach, na osiedlu Przyjaźni (ryc. 1). Oba parki doczekały się licznych opracowań studialno-realizacyjnych, w których zaprezentowano przykłady projektów i koncepcji projektowych w zakresie inwentaryzacji, estetyzacji, rewaloryzacji, modernizacji oraz kolejnych wariantów zagospodarowania przestrzennego.

Opracowania te powstały $\mathrm{w}$ ramach realizacji programu studiów na kierunku architektura krajobrazu, w Katedrze Terenów Zieleni i Architektury Krajobrazu Uniwersytetu Przyrodniczego w Poznaniu. Swiadczy to o stałej pamięci o Profesorach i zaangażowaniu kadry naukowo-dydaktycznej kierunku architektura 


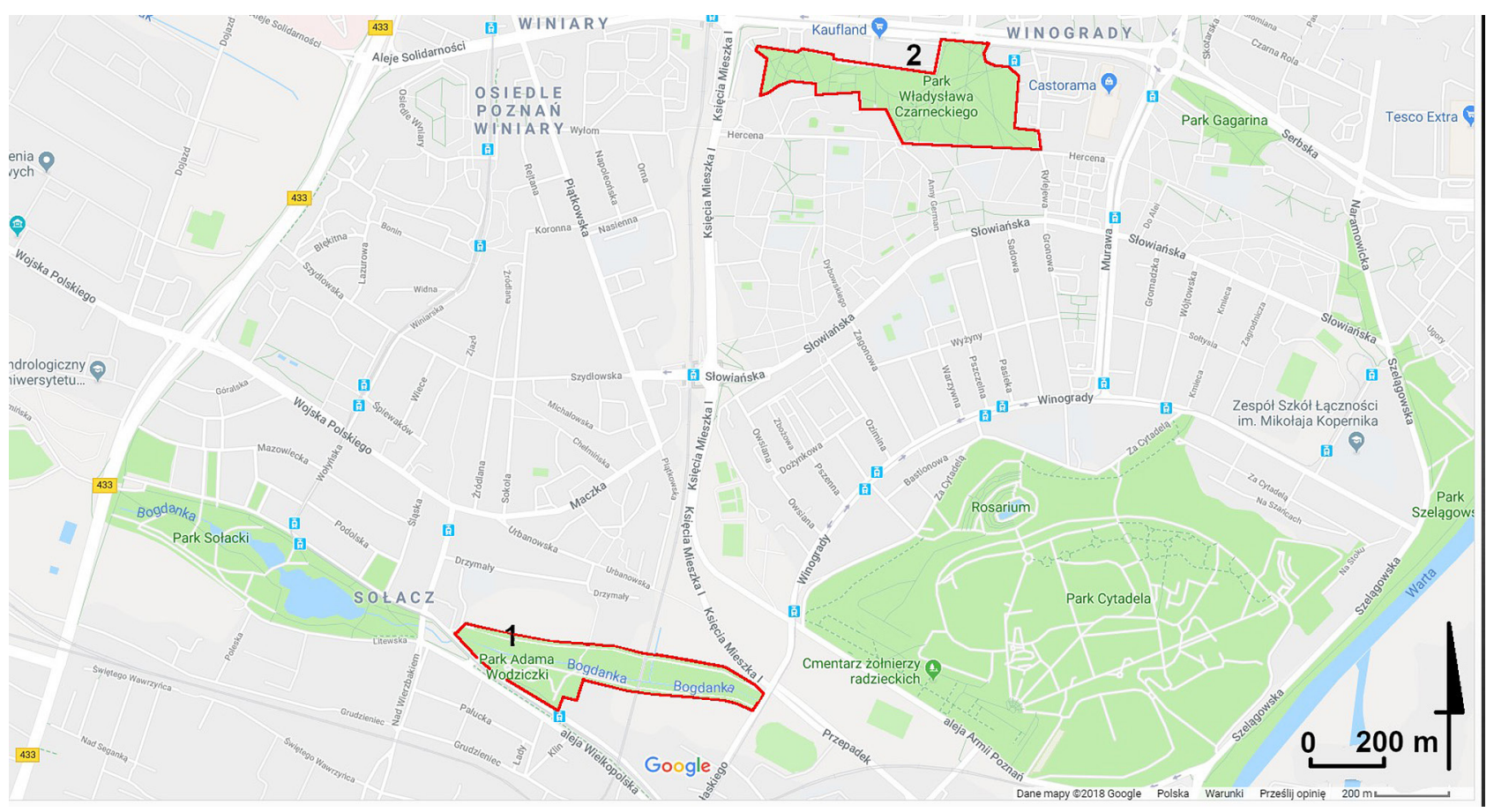

Ryc. 1. Lokalizacje parków im. A. Wodziczki i W. Czarneckiego na terenie miasta Poznań: 1 - Park Adama Wodziczki, 2 Park Władysława Czarneckiego

Źródło: opracowanie P. P. Szumigała, K. Szumigała.

Fig. 1. Locations of named after A. Wodziczko and W. Czarnecki in the city of Poznań: 1 - Adam Wodziczko Park, 2 Władysław Czarnecki Park

Source: compilation P. P. Szumigała, K. Szumigała.

krajobrazu w utrzymanie parków w dobrej kondycji estetycznej i funkcjonalno-krajobrazowej. Tym bardziej że osoby profesorów Adama Wodziczki i Władysława Czarneckiego, których imiona noszą te tereny, są ściśle związane z problematyką i treściami nauczania na kierunku architektura krajobrazu. Profesorowie to postacie wybitne, a ich osiągnięcia naukowe są szczególnie istotne dla przestrzeni Poznania i okolic.

\section{SYLWETKI PROFESORÓW ADAMA WODZICZKI I WŁADYSŁAWA CZARNECKIEGO}

Profesor Adam Wodziczko (fot. 1A) był jedną z pierwszych i nielicznych osób, które rozpoczęły szeroką kampanię naukową na rzecz ochrony naturalnego środowiska - przyrody, zieleni i krajobrazu. Jego zasługą jest utworzenie trzech parków narodowych: Wolińskiego, Słowińskiego i Wielkopolskiego. Adam Wodziczko był propagatorem idei wprowadzania zieleni na terenach niezabudowanych i słońca do zwartej zabudowy miasta. W 1925 roku powołał do życia Ligę Ochrony Przyrody na terenie Wielkopolski i Pomorza. W czasie II wojny światowej profesor prowadził tajne nauczanie w Krakowie, a w Poznaniu warsztaty twórczej pracy naukowej.

Profesor Władysław Czarnecki (fot. 1B) był architektem, który w latach 1930-1933, w oparciu o istniejące walory środowiska i koncepcje Stübbena z roku 1914, zaprojektował pierścieniowo-klinowy system

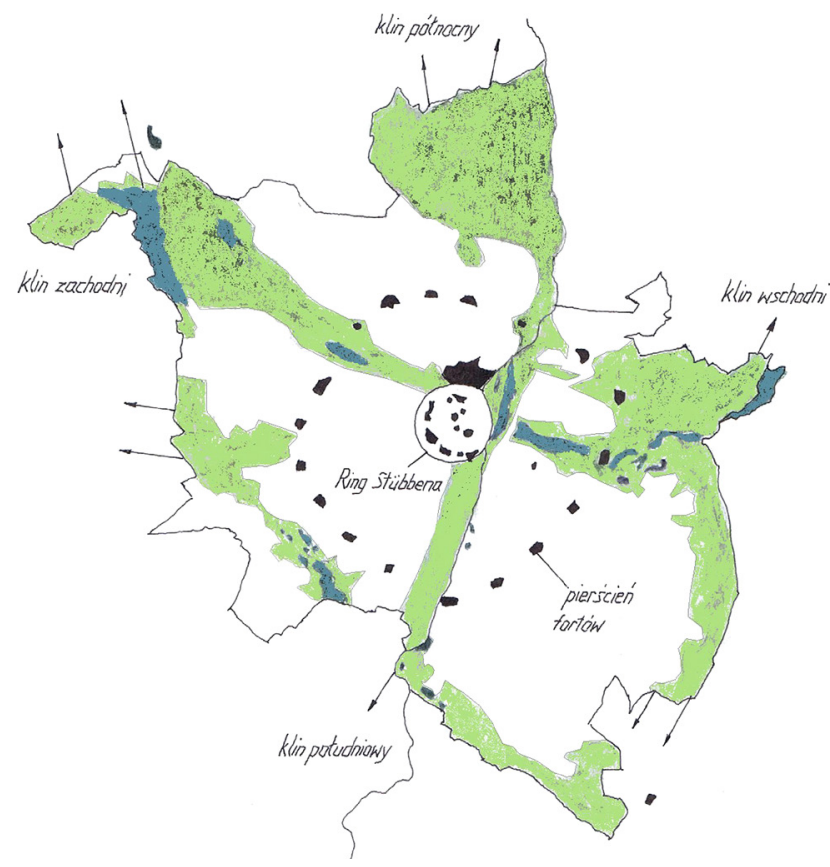

Ryc. 2. Pierścieniowo-klinowy system zieleni miasta Poznań według prof. W. Czarneckiego

Źródło: opracowanie S. Sosnowska na podstawie CZARNeCKI (1961).

Fig. 2. The ring wedge green system of the city of Poznan according to Prof. W. Czarnecki

Source: compilation S. Sosnowska, based on CZARNECKI (1961). 

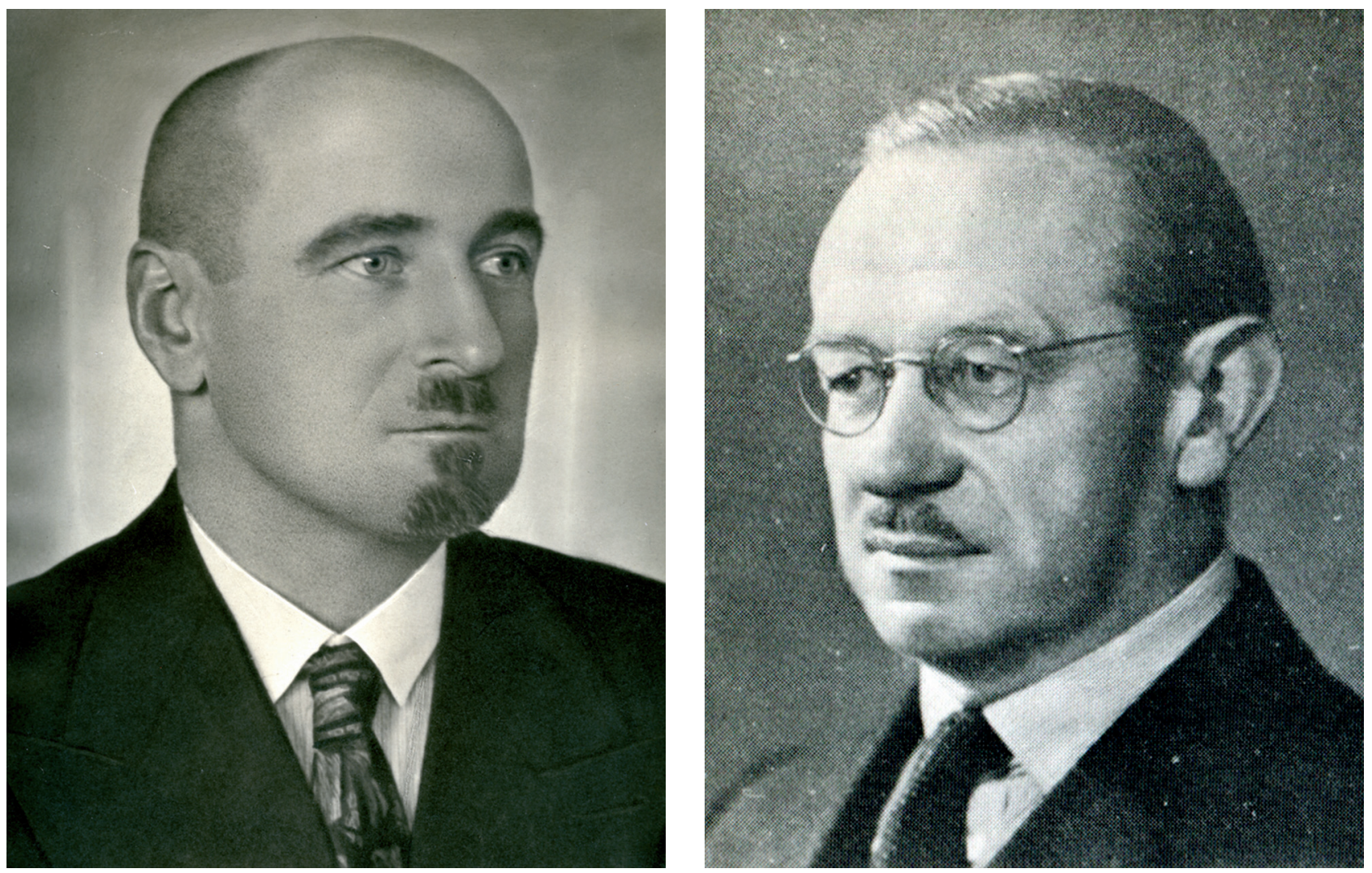

Fot. 1. Adam Wodziczko (po lewej) i Władysław Czarnecki (po prawej)

Źródło: archiwum Bogucki Wydawnictwo Naukowe.

Photo 1. Adam Wodziczko (left) and Władysław Czarnecki (right)

Source: archive Bogucki Wydawnictwo Naukowe.

zieleni miasta Poznania. W tym czasie W. Czarnecki kierował rozbudową Poznania i wówczas podjęto decyzje o objęciu ochroną obszaru w promieniu 25 $\mathrm{km}$ od centrum miasta, w którym mieściły się naturalne kliny zieleni. System klinowy miał uzupełniać pierścień zieleni zaplanowany na terenach dawnych wałów obronnych miasta oraz pierścień zewnętrzny przebiegający przez Ławicę, Naramowice, Chartowo, Starołękę, Dębiec i Świerczewo (ŁuKAsIEwicz 1982, Kodyм-KozAczKo 2011). Koncepcja W. Czarneckiego opierała się na czterech głównych klinach zlokalizowanych wzdłuż rzek: Warty, Bogdanki i Cybiny. W skład klinów zaliczono obszary zieleni o różnej strukturze: klin północny (naramowicki) tworzą lasy komunalne, ogrody działkowe i łąki położone wzdłuż północnego odcinka doliny Warty, klin wschodni (cybiński) obejmuje obszar parku Tysiąclecia, Jezioro Maltańskie, cmentarz komunalny na Miłostowie, lasy Białej Góry oraz Wielkopolski Park Zoologiczny (MierzejEWsKA 2001), klin południowy (dębiński) to łąki zalewowe występujące $\mathrm{w}$ sąsiedztwie południowej części doliny Warty, park im. Jana Pawła II oraz kompleks leśny Dębina, na klin zachodni (golęciński) składają się obszary zieleni zlokalizowane wzdłuż doliny Bogdanki, lasek Golęciński, jeziora: Kierskie, Strzeszyńskie i Rusałka, kompleks sportowy „Olimpia”, a także parki: Sołacki, im. A. Wodziczki i Cytadela oraz ogrody działkowe (ryc. 2). Poza działaniami na rzecz ochrony zieleni prof. W. Czarnecki był znakomitym architektem i urbanistą, który pozostawił w Poznaniu wiele znaczących obiektów architektonicznych, między innymi: Dom Żołnierza - ul. Ratajczaka, dawny gmach KW PZPR u zbiegu ulic Święty Marcin i Kościuszki - obecnie Wydział Nauk Humanistycznych UAM, Wojewódzki Ośrodek Zdrowia - ul. Słowackiego, domy wielorodzinne i budynek Magnolii przy parku Wilsona - ul. Głogowska, budynki szeregowe przy ulicy Szamotulskiej, domy jednorodzinne dla tramwajarzy przy ul. Grodzkiej. Prowadził odbudowę Biblioteki Raczyńskich, był także współautorem projektu kościoła Dominikanów przy al. Niepodległości oraz zespołu kościelno-klasztornego sióstr urszulanek w Pniewach. Opublikował liczne opracowania naukowe, między innymi doniosłe sześciotomowe dzieło „Planowanie miast i osiedli”.

\section{MATERIAŁ I METODY}

\section{ZAŁOŻENIA KOMPOZYCYJNE I FUNKCJONALNO-PRZESTRZENNE PARKÓW A. WODZICZKI I W. CZARNECKIEGO W POZNANIU}

W artykule przedstawiono syntetycznie wyniki badań i koncepcje zagospodarowania parków im. A. Wodziczki i W. Czarneckiego na podstawie pięciu 
prac magisterskich wykonanych w Katedrze Terenów Zieleni i Architektury Krajobrazu Uniwersytetu Przyrodniczego w Poznaniu. W opracowaniach ukazano rozwój i ewolucję współczesnych myśli i poglądów dotyczących kształtowania przestrzeni oraz zasad projektowania, modernizacji, estetyzacji i rewaloryzacji obiektów zieleni publicznej. Zastosowano w nich metodę analizy przypadku w kontekście współczesnych trendów projektowych.

\section{PARK ADAMA WODZICZKI}

Park powstał w latach 1971-1972. Obejmuje teren o powierzchni 7 ha, na którym rośnie około dwóch tysięcy drzew reprezentujących 54 gatunki. Historia powstania parku sięga 1907 roku, w którym H.J. Stübben, jako przewodniczący Królewskiej Komisji Rozbudowy Miasta Poznania, opracował na zlecenie zarządu miejskiego plan nowej kolonii willowej przeznaczonej dla niemieckich urzędników. Plan zakładał rozparcelowanie majątku Sołacz i utworzenie na jego terenie dzielnicy pełnej zieleni, która miała odzwierciedlać howardowską ideę miasta ogrodu. W planie Stübbena centralną część osiedla zajmował nowo utworzony naturalistyczny park z dwoma sztucznymi zbiornikami wodnymi - stawami. Ze względu na potrzeby współczesnych mieszkańców konieczna jest dywersyfikacja pierwotnego programu funkcjonalno-przestrzennego parku Adama Wodziczki. W myśl obecnych trendów w projektowaniu obszarów zieleni miejskiej konieczne jest uwzględnianie i zaspokajanie potrzeb coraz większej liczby użytkowników, o różnych upodobaniach i w różnym wieku. W projekcie studenta Łukasza Mrowińskiego z 2006 roku w par$\mathrm{ku}$ przewidziano lokalizację nowego placu zabaw, likwidację toru rowerowego, wymianę nawierzchni dróg uszkodzonych przez korzenie drzew, zniwelowanie rzędnej wysokości nawierzchni alei północnej,

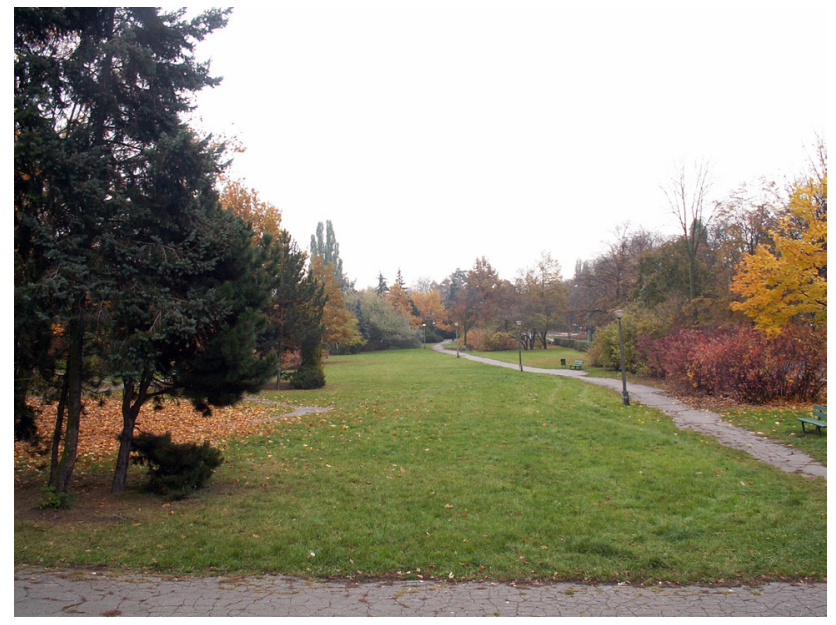

Fot. 2. Park Adama Wodziczki - jesień 2016, przed rewaloryzacją (fot. P. Tomczak)

Phot. 2. Adam Wodziczko Park - autumn 2016, before revalorisation (photo P. Tomczak)

wymianę latarni i ławek oraz pojemników na odpady, budowę schodów nad ciepłociągiem przecinającym drogę parkową oraz powszechną renowację zieleni, która poprawi jej kondycję i widoczność na obszarze parku. Nowy projekt z 2012, opracowany przez Annę Kowalską, uwzględnia powyższe propozycje i rozszerza program użytkowy o nowy układ dróg i nowe kompozycje nasadzeń w strefie centralnej parku (ryc. $3 \mathrm{~A} \mathrm{i} \mathrm{B,} \mathrm{fot.} \mathrm{2).}$

W 2007 roku powstał kolejny projekt zagospodarowania parku Adama Wodziczki, autorstwa Anny Demskiej, który zakłada oczyszczenie i przebudowę zamulonego zbiornika (poprawne ukształtowanie dna zbiornika i zastosowanie mnichów wodnych do regulacji poziomu i przepływu wody), estetyzację koryta i dopływów rzeczki Bogdanki w obrębie parku (budowę kilku nowych kładek i mostków), remont nawierzchni drogi parkowej oraz wydzielenie
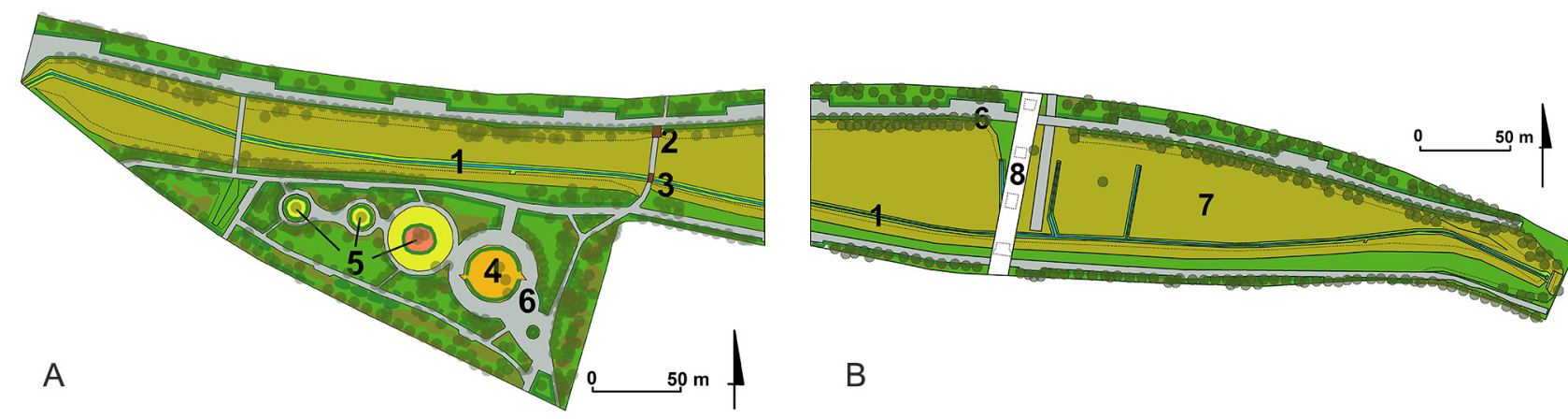

B

Ryc. 3. Plan zagospodarowania parku Adama Wodziczki w Poznaniu z 2012 roku: A - część zachodnia, B - część wschodnia, 1 - rzeka Bogdanka, 2 - schody, 3 - mostek, 4 - plac zabaw dla dzieci, 5 - ozdobne klomby, 6 - ścieżki utwardzone, 7 - wybieg dla psów, 8 - estakada szybkiego tramwaju

Źródło: opracowanie P. P. Szumigała, K. Szumigała na podstawie KowALSKA (2012).

Fig. 3. Development Plan of Adam Wodziczko Park in Poznań from 2012: A - western part, B - eastern part, 1 - Bogdanka river, 2 - stairs, 3 - bridge, 4 - playground for children, 5 - decorative flower beds, 6 - paved paths, 7 - catwalk for dogs, 8 - flyover for fast tram

Source: compilation P. P. Szumigała, K. Szumigała on the basis of KowALSKA (2012). 


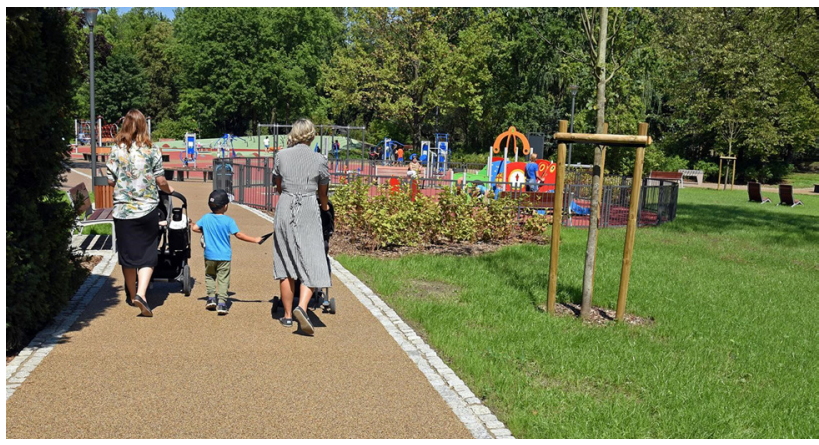

Fot. 3. Park Adama Wodziczki - lato 2018, po rewaloryzacji Źródło: http://www.poznan.pl/mim/info/news/park-wodziczkimiejsce-do-zabawy-i-wypoczynku,121242.html (dostęp: 10.2018).

Phot. 3. Adam Wodziczko Park - summer 2018, after revalorisation

Source: http://www.poznan.pl/mim/info/news/park-wodziczkimiejsce-do-zabawy-i-wypoczynku,121242.html (access: 10.2018).

zielenią pasa drogi rowerowej, renowację zieleni, modernizację i wymianę elementów małej architektury (latarnie, ławki, kosze na odpady, stojaki na rowery, altana parkowa). W opracowaniu zwrócono uwagę na uciążliwość, jaką jest hałas tramwaju przejeżdżającego po betonowej estakadzie, która przebiega nad parkiem. Również konstrukcja i lokalizacja estakady wpływają niekorzystnie na estetykę przestrzeni tego miejsca.

Dlatego w opracowaniu Demskiej zaproponowano usytuowanie niskich ekranów wygłuszających wzdłuż balustrad estakady oraz maskowanie jej konstrukcji nasadzeniami pnączy i roślin ozdobnych w donicach i w gruncie.

W koncepcji Anny Kowalskiej z 2012 roku odnotowano także potrzebę wymiany nawierzchni dróg i małej architektury (latarni, ławek) oraz korektę przebiegu dróg, gdyż użytkownicy, skracając sobie drogę przez park, tworzą tzw. „przedepty”. Obecnie,

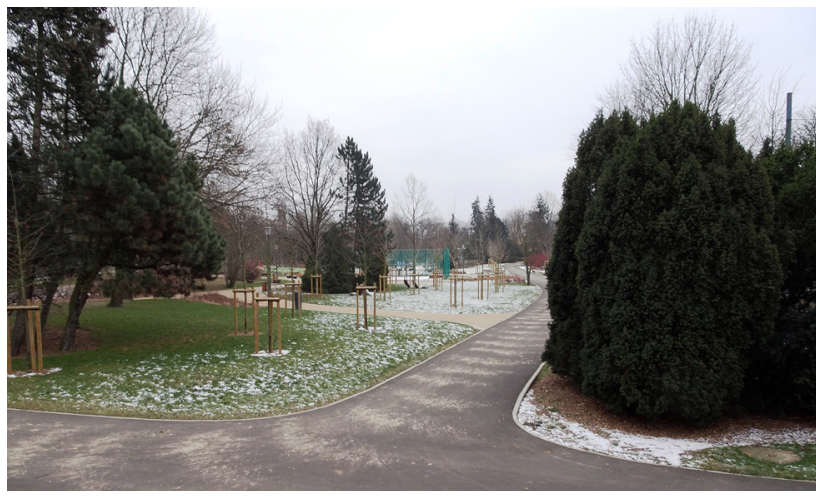

Fot. 4. Park Adama Wodziczki po rewaloryzacji (fot. G. Kołodziejewski)

Phot. 4. Adam Wodziczko Park after revalorisation (photo G. Kołodziejewski)

dzięki wykorzystaniu zaleceń zawartych w pracach dyplomowych, park Wodziczki odzyskał swą dawną świetność (ryc. 2, fot. 3, 4).

\section{PARK WŁADYSŁAWA CZARNECKIEGO}

Park powstał w latach 90. XX wieku z inicjatywy Zarządu Zieleni Miejskiej. Imię swojego patrona uzyskał decyzją Rady Miasta Poznania z dnia 25 marca 2003 roku. Z punktu widzenia współczesnych użytkowników parku istotna była poprawa funkcjonalności i estetyki parku (ANDRZEJEwsKA 2006). Konieczne zatem okazało się zaprojektowanie i wydzielenie różnych stref funkcjonalnych połączone $z$ zachowaniem istniejącego układu komunikacyjnego oraz systemu nasadzeń, składającego się z kilkuset dwudziestoletnich drzew i krzewów. Jednym $z$ ważniejszych zadań stało się również rozwiązanie konfliktu pomiędzy rodzicami (opiekunami dzieci) a właścicielami psów. W rezultacie

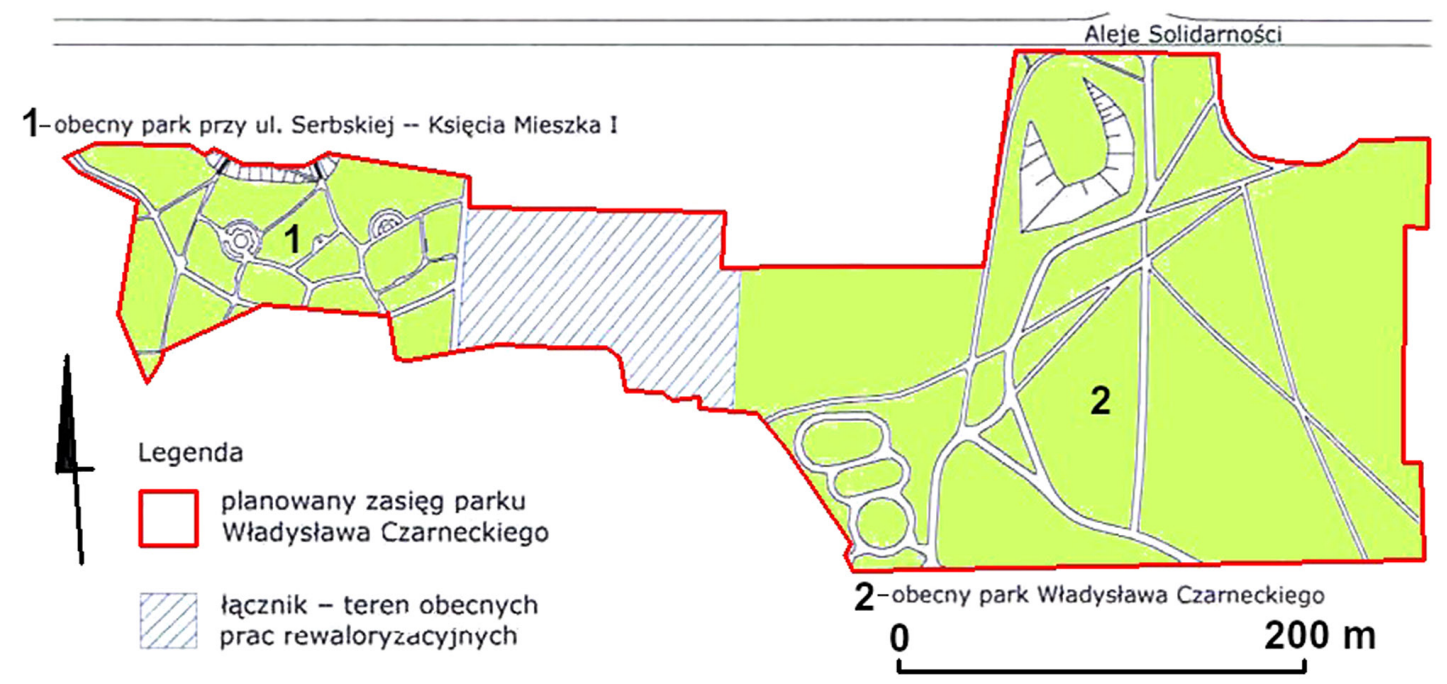

Ryc. 4. Projekt powiększenia parku Władysława Czarneckiego z 2006 roku Źródło: opracowanie P.P. Szumigała, K. Szumigała na podstawie ANDRZEJewsKA (2006).

Fig. 4. The concept to enlarge Władysław Czarnecki Park from 2006

Source: study by P.P. Szumigała, K. Szumigała on the basis of ANDRZEJewSKA (2006). 


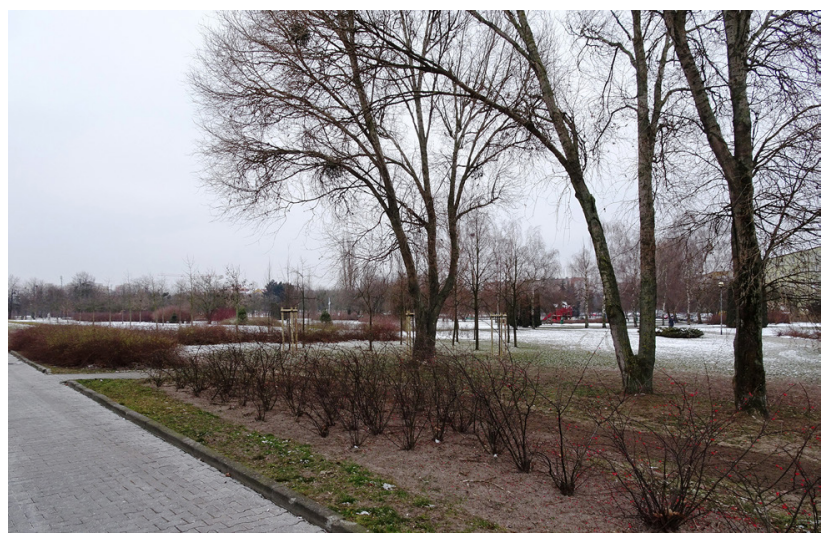

Fot. 5. Park Władysława Czarneckiego (fot. P. Urbański) Phot. 5. Władysław Czarnecki Park (photo P. Urbański)

powstał projekt zagospodarowania parku o bogatym programie użytkowo-funkcjonalnym, na który składają się: plac zabaw dla dzieci młodszych i starszych, górka saneczkowa, łąki do zabaw zbiorowych, skatepark, ogrody tematyczne (wiosenny, jesienny, traw, barw i słońca), a także kilka placów do gier planszowych, pojemniki na odpady, nawierzchnie ścieżek i oświetlenie oraz ogrodzony wybieg dla psów, wyposażony w toalety dla psów i siedziska dla opiekunów.

W koncepcji AndRZejewskiej (2006) przewidziano połączenie funkcjonalne i strukturalne parku Władysława Czarneckiego, $z$ istniejącym w pobliżu parkiem przy ulicy Serbskiej, przez niezabudowany teren znajdujący się pomiędzy tymi parkami. W ten sposób uzyskano większy obszar zieleni, który stanowi nową jakość przestrzenną i jest istotnym elementem krajobrazu tej części Poznania. Powierzchnia parku wzrosła do ok. 12 ha. W 2014 roku na tym terenie urządzono siłownie na powietrzu dla osób starszych. W parku znajduje się pomnik Władysława Czarneckiego, $z$ datami jego urodzin i śmierci, ufundowany przez Stowarzyszenie Architektów Polskich. Zachowały się w nim betonowe bloki z cumami (metalowymi obręczami), które służyły do mocowania lądujących sterowców, obok nieistniejącej już hali zeppelinów (ryc. 4, fot. 3).

W 2016 roku powstała nowa koncepcja modernizacji parku zawarta w pracy Marty Korzuchowskiej. Opracowaniem objęto część zachodnią parku, który

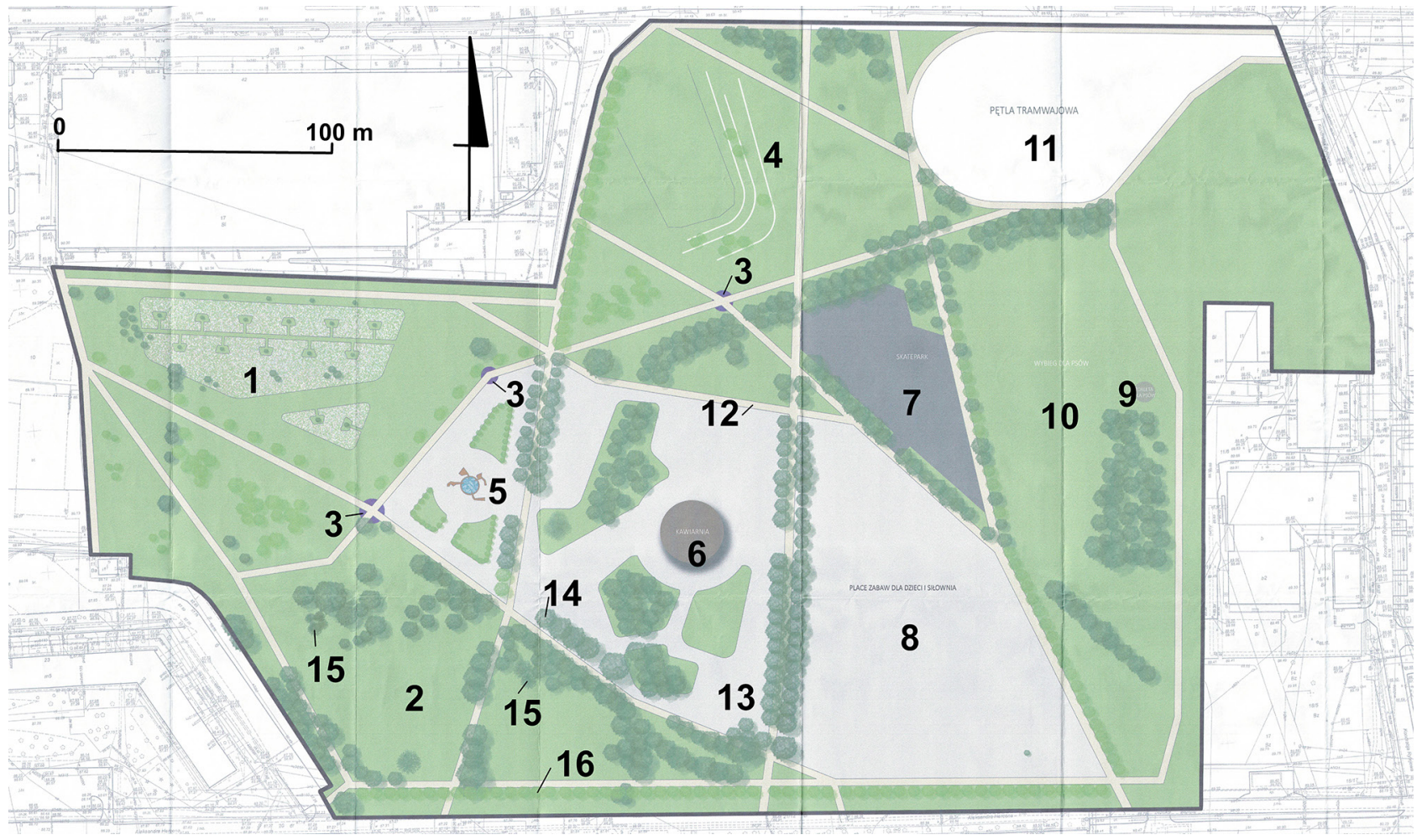

Ryc. 5. Plan zagospodarowania parku Władysława Czarneckiego w Poznaniu z 2016 roku: 1 - łąka kwietna, 2 - trawnik, 3 - byliny, 4 - siedziska, 5 - forma plastyczna - fontanna, 6 - kawiarnia, 7 - skatepark, 8 - plac zabaw dla dzieci, 9 toaleta dla psów, 10 - wybieg dla psów, 11 - pętla tramwajowa, 12 - ścieżki o nawierzchni utwardzonej i przepuszczalnej - Terraway, 13 - nawierzchnia z kostki betonowej, 14 - istniejące drzewa liściaste 15 - istniejące drzewa iglaste, 16 - drzewa projektowane

Źródło: opracowanie P.P. Szumigała, K. Szumigała na podstawie KorzuchowsKa (2016).

Fig. 5. Development Plan of Władysław Czarnecki Park in Poznań from 2016: 1 - flower meadow, 2 - lawn, 3 - perennials, 4 - seats, 5 - artistic form - fountain, 6 - cafe, 7 - skatepark, 8 - children's playground, 9 - dog toilet, 10 - catwalk, 11 - tramway loop, 12 - pavement with hardened and permeable surface - Terraway, 13 - concrete pavement, 14 - existing deciduous trees 15 - existing conifeuros trees, 16 - trees under development

Source: compilation P.P. Szumigała, K. Szumigała on te basis of KorzuchowsKa (2016). 
Tabela 1. Wykaz projektowanych roślin w parku Adama Wodziczki w 2016 roku

Table 1. List of projected plants in Adam Wodziczko Park in 2016

\begin{tabular}{|c|c|c|c|}
\hline $\begin{array}{l}\mathrm{Nr} \\
\mathrm{No}\end{array}$ & $\begin{array}{c}\text { Nazwa łacińska } \\
\text { Latin name }\end{array}$ & $\begin{array}{l}\text { Nazwa polska } \\
\text { Polish name }\end{array}$ & $\begin{array}{c}\text { Liczba } \\
\text { Number }\end{array}$ \\
\hline 1. & Acer tataricum L. subsp. ginnala & klon tatarski podgatunek ginnala & 4 \\
\hline 2. & Betula pendula Roth 'Youngii' & brzoza brodawkowata 'Youngii' & 2 \\
\hline 3. & Crataegus x media Bechst. 'Paul's Scarlet' & głóg dwuszyjkowy ‘Pauls’s Scarlet & 13 \\
\hline 4. & Ilex aquifolium $\mathrm{L}$. & ostrokrzew kolczasty & 10 \\
\hline 5. & Prunus padus L. 'Colorata' & czeremcha pospolita 'Colorata' & 18 \\
\hline 6. & Prunus serotina Ehrh. & czeremcha amerykańska & 14 \\
\hline 7. & Rhus typhina L. & sumak octowiec & 10 \\
\hline 8. & Salix $\times$ sepulcralis Simonk. 'Chrysocoma' & wierzba płacząca & 2 \\
\hline 9. & Berberis thunbergii DC. 'Atropurpurea' & berberys Tunberga 'Atropurpurea' & 29 \\
\hline 10. & Buddleja davidii Franch. 'Royal Red' & budleja Dawida 'Royal Red' & 17 \\
\hline 11. & Chaenomeles Japonica Thunb. & pigwowiec japoński & 9 \\
\hline 12. & Cotoneaster horizontalis Decne. & irga pozioma & 12 \\
\hline 13. & Deutzia scabra Thunb. & żylistek szorstki & 17 \\
\hline 14. & Euonymus fortunei Turcz. 'Coloratus' & trzmielina Fortune’a ‘Coloratus' & 9 \\
\hline & Mahonia aquifolium Pursh & mahonia pospolita & 9 \\
\hline 16. & Philadelphus coronarius L. & jaśminowiec wonny & 29 \\
\hline 17. & Physocarpus opulifolius L. & pęcherznica kalinolistna & 53 \\
\hline 18. & Physocarpus opulifolius L. 'Diabolo' & pęcherznica kalinolistna 'Diabolo' & 24 \\
\hline & Physocarpus opulifolius L. 'Luteus' & pęcherznica kalinolistna 'Luteus' & 19 \\
\hline & Potentilla frutiosa L. 'Abbotswood' & pięciornik krzewiasty 'Abbotswood' & 26 \\
\hline & Potentilla frutiosa L. 'Goldfinger’ & pięciornik krzewiasty 'Goldfinger' & 14 \\
\hline & Potentilla frutiosa L. 'Pink Queen' & pięciornik krzewiasty ‘Pink Queen’ & 9 \\
\hline & Sambucus nigra $\mathrm{L}$. & bez czarny & 28 \\
\hline & Spiraea betulifolia L. & tawuła brzozolistna & 50 \\
\hline & Spiraea densifolia $\mathrm{L}$. & tawuła gęstokwiatowa & 19 \\
\hline & Juniperus communis L. 'Green Carpet' & jałowiec pospolity ‘Greend Carpet’ & 6 \\
\hline & Juniperus communis L. 'Repanda' & jałowiec pospolity 'Repanda' & 18 \\
\hline & Juniperus horizontalis Moench ‘Blue Chip’ & jałowiec płożący ‘Blue Chip’ & 14 \\
\hline 29. & Juniperus horizontalis Moench 'Golden Carpet' & jałowiec płożący ‘Golden Carpet’ & 5 \\
\hline 30. & Fallopia baldschuanica Holub. & rdestówka Auberta & 2 \\
\hline & Hedera helix $\mathrm{L}$. & bluszcz pospolity & 4 \\
\hline & Parthenocissus quinquefolia L. & winobluszcz pięciolistkowy & 20 \\
\hline 33. & Acorus calamus L. & tatarak zwyczajny & $60^{*}$ \\
\hline & Acorus calamus L. 'Variegata' & tatarak zwyczajny 'Variegata' & $75^{*}$ \\
\hline 35. & Astilbe $\times$ arendsii Arends 'Feuer' & tawułka Arendsa 'Feuer' (7) & 460 \\
\hline 36. & Astilbe $\times$ arendsii Arends 'Showstar' & tawułka Arendsa 'Showstar' (7) & 680 \\
\hline 37. & Caltha palustris L. & kaczeniec błotny (9) & 700 \\
\hline 38. & Dianthus deltoids L. 'Albiflorus' & goździk kropkowany 'Albiflorus' (9) & 180 \\
\hline 39. & Dianthus deltoids L. & goździk kropkowany (9) & 150 \\
\hline & Eichornia crassipes Mart. & hiacynt wodny & $6^{*}$ \\
\hline & Eleocharis palustris (L.) Roem & panikło błotne & $150^{*}$ \\
\hline 42. & Glyceria maxima hartm. Holmb. 'Variegata' & manna mielec 'Variegata' (3) & 65 \\
\hline 43. & Hippurius vulgaris L. & przęstka pospolita & $150^{*}$ \\
\hline & Houstonia cearulea & houstonia błękitna (11) & 300 \\
\hline & Iris sibirica $\mathrm{L}$. & kosaciec syberyjski (7) & 220 \\
\hline & Menyanthes trifoliata $\mathrm{L}$. & bobrek trójlistkowy & $100^{*}$ \\
\hline & Molinia coerulea L. (Moench.) 'Variegata' & trzęślica modra 'Variegata' (9) & 350 \\
\hline & Myosotis palustris L. (Nath.) & niezapominajka błotna (9) & 800 \\
\hline & Nuphar lutea L. Sibith. & grążel żółty & $5^{*}$ \\
\hline 50. & Polygonum amphibium $\mathrm{L}$. & rdest ziemnowodny & $160^{*}$ \\
\hline 51. & Potamogeton natans $\mathrm{L}$. & rdestnica pływająca & $200^{*}$ \\
\hline
\end{tabular}


Tabela $1-$ cd.

Table 1 - continued

\begin{tabular}{lllc}
\hline Nr & \multicolumn{1}{c}{$\begin{array}{c}\text { Nazwa łacińska } \\
\text { Latin name }\end{array}$} & \multicolumn{1}{c}{$\begin{array}{c}\text { Nazwa polska } \\
\text { Polish name }\end{array}$} & $\begin{array}{c}\text { Liczba } \\
\text { Number }\end{array}$ \\
\hline 52. & Ranunculus acris L. 'Multiplex' & jaskier ostry 'Multiplex' (9) & 450 \\
53. & Thymus praecox Opiz. 'Coccineus' & macierzanka wczesna 'Coccineus' (16-25) & 150 \\
54. & Thymus serpyllum L. & macierzanka piaskowa (16) & 200 \\
55. & Trollius europaeus L. & pełnik europejski (9) & 450 \\
56. & Typha angustifolia L. & pałka wąskolistna (3) & 60 \\
57. & Typha minima L. & pałka drobna (5) & 75 \\
\hline
\end{tabular}

*Rośliny ekspansywne, dlatego ich liczbę podano w minimalnych ilościach.

Liczbę pozostałych gatunków bylin obliczono na podstawie zajmowanej przez nie powierzchni i zalecanej liczby roślin na $1 \mathrm{~m}^{2}$. Wartość tę podano przy nazwie polskiej w nawiasie.

Źródło: P.P. Szumigała na podstawie KowALSKA (2016).

*Expansionary plants, therefore their number is given in minimum quantities.

The number of other perennial species was calculated on the basis of their area and the recommended number of plants per $1 \mathrm{~m}^{2}$. This value is given next to the Polish name in brackets.

Source: P.P Szumigała on the basis of KowALSKA (2016).

Tabela 2. Wykaz materiałów na nawierzchnie przewidziane do rewaloryzacji w parku A. Wodziczki w Poznaniu w 2006 roku

Table 2. List of materials for surfaces to be revalorised in Park A. Wodziczko in Poznań in 2006

\begin{tabular}{|c|c|c|c|c|}
\hline $\begin{array}{l}\mathrm{Nr} \\
\mathrm{No}\end{array}$ & $\begin{array}{l}\text { Nazwa obiektu } \\
\text { Object name }\end{array}$ & $\begin{array}{l}\text { Element wyposażenia } \\
\text { Element of equipment }\end{array}$ & $\begin{array}{l}\text { Typ/wymiary } \\
\text { Type/Dimen- } \\
\text { sions }\end{array}$ & $\begin{array}{c}\text { Ilość }\left(\mathrm{m}^{2}, \mathrm{~m}^{3},\right. \\
\text { m b., sztuki) } \\
\text { Quantity (m², } \mathrm{m}^{3}, \\
\text { rm, pieces) }\end{array}$ \\
\hline \multirow[t]{3}{*}{1.} & Zespół trzech placyków & kostka Nostalit firmy BRUK-BET & szara & $225 \mathrm{~m}^{2}$ \\
\hline & & kostka Nostalit firmy BRUK-BET & czarna & $25 \mathrm{~m}^{2}$ \\
\hline & & krawężnik EKO-BORD & - & $54 \mathrm{~m} \mathrm{~b}$. \\
\hline & Plac lipowy & kostka Nostalit firmy BRUK-BET & szara & $112 \mathrm{~m}^{2}$ \\
\hline & & kostka Nostalit firmy BRUK-BET & czarna & $7 \mathrm{~m}^{2}$ \\
\hline & & krawężnik EKO-BORD & - & $66 \mathrm{~m} \mathrm{~b}$. \\
\hline \multirow[t]{3}{*}{3.} & Plac - północny ogród traw & kostka Nostalit firmy BRUK-BET & szara & $45 \mathrm{~m}^{2}$ \\
\hline & & kostka Nostalit firmy BRUK-BET & czarna & $5 \mathrm{~m}^{2}$ \\
\hline & & krawężnik EKO-BORD & - & $25 \mathrm{~m} \mathrm{~b}$ \\
\hline \multirow[t]{3}{*}{4.} & Plac - południowy ogród traw & kostka Nostalit firmy BRUK-BET & szara & $25 \mathrm{~m}^{2}$ \\
\hline & & kostka Nostalit firmy BRUK-BET & czarna & $3 \mathrm{~m}^{2}$ \\
\hline & & krawężnik EKO-BORD & - & $19 \mathrm{~m} \mathrm{~b}$ \\
\hline \multirow[t]{3}{*}{5.} & Plac - ogród słońca & kostka Nostalit firmy BRUK-BET & szara & $45 \mathrm{~m}^{2}$ \\
\hline & & kostka Nostalit firmy BRUK-BET & czarna & $5 \mathrm{~m}^{2}$ \\
\hline & & krawężnik EKO-BORD & - & $25 \mathrm{~m} \mathrm{~b}$ \\
\hline & Place łącznie & kostka Nostalit firmy BRUK-BET & szara & $482 \mathrm{~m}^{2}$ \\
\hline & & kostka Nostalit firmy BRUK-BET & czarna & $45 \mathrm{~m}^{2}$ \\
\hline & & krawężnik EKO-BORD & - & $189 \mathrm{~m} \mathrm{~b}$. \\
\hline & & podsypka piaskowo-cementowa & - & $27 \mathrm{~m}^{3}$ \\
\hline & & tłuczeń & $1-63 \mathrm{~mm}$ & $80 \mathrm{~m}^{3}$ \\
\hline & Drogi zaprojektowane & kostka Nostalit firmy BRUK-BET & szara, $12 \times 12 \mathrm{~cm}$ & $730 \mathrm{~m}^{2}$ \\
\hline & & krawężnik EKO-BORD & - & $680 \mathrm{~m}^{2}$ \\
\hline & & podsypka piaskowo-cementowa & - & $37 \mathrm{~m}^{3}$ \\
\hline & & tłuczeń & $1-63 \mathrm{~mm}$ & $110 \mathrm{~m}^{3}$ \\
\hline & Obecne drogi gruntowe & kostka Nostalit firmy BRUK-BET & szara, $12 \times 12 \mathrm{~cm}$ & $1830 \mathrm{~m}^{2}$ \\
\hline & & krawężnik EKO-BORD & - & $1430 \mathrm{~m} \mathrm{~b}$ \\
\hline & & podsypka piaskowo-cementowa & - & $92 \mathrm{~m}^{3}$ \\
\hline & & tłuczeń & $1-63 \mathrm{~mm}$ & $275 \mathrm{~m}^{3}$ \\
\hline \multirow{2}{*}{\multicolumn{2}{|c|}{ 9. Skate park }} & asfalt $1200 \mathrm{~m}^{2}$ & - & $1200 \mathrm{~m}^{2}$ \\
\hline & & tłuczeń & $1-63 \mathrm{~mm}$ & $180 \mathrm{~m}^{2}$ \\
\hline \multirow{2}{*}{\multicolumn{2}{|c|}{ 10. Plac zabaw dla dzieci starszych }} & piasek gruboziarnisty $-400 \mathrm{~m}^{2}$ & - & $60 \mathrm{~m}^{3}$ \\
\hline & & płytki chodnikowe & $30 \times 30 \mathrm{~cm}$ & 27 sztuk \\
\hline
\end{tabular}


Tabela 2 - cd.

Table 2 - continued

\begin{tabular}{|c|c|c|c|c|}
\hline $\begin{array}{l}\mathrm{Nr} \\
\mathrm{No}\end{array}$ & $\begin{array}{l}\text { Nazwa obiektu } \\
\text { Object name }\end{array}$ & $\begin{array}{l}\text { Element wyposażenia } \\
\text { Element of equipment }\end{array}$ & $\begin{array}{l}\text { Typ/wymiary } \\
\text { Type/Dimen- } \\
\text { sions }\end{array}$ & $\begin{array}{c}\text { Ilość }\left(\mathrm{m}^{2}, \mathrm{~m}^{3},\right. \\
\text { m b., sztuki) } \\
\text { Quantity (m², } \mathrm{m}^{3}, \\
\text { rm, pieces) }\end{array}$ \\
\hline & Plac zabaw dla najmłodszych & piasek wewnątrz i wokół piaskownicy & - & $8 \mathrm{~m}^{3}$ \\
\hline & i ich opiekunów & piasek gruboziarnisty wokół urządzeń zabawowych 150 m² & - & $22 \mathrm{~m}^{3}$ \\
\hline 12. & Ogród zapachów & żwir jasny $-4 \mathrm{~m}^{2}$ & - & $0,2 \mathrm{~m}^{3}$ \\
\hline & Ogród barw - narożniki & żwir jasny $-5,5 \mathrm{~m}^{2}$ & - & $0,3 \mathrm{~m}^{3}$ \\
\hline 14. & Ogród traw - ściółka & żwir jasny - $290 \mathrm{~m}^{2}$ & - & $14 \mathrm{~m}^{3}$ \\
\hline \multirow[t]{4}{*}{15.} & Wybieg dla psów & piasek do toalet & - & $4 \mathrm{~m}^{3}$ \\
\hline & & płytki chodnikowe & $30 \times 30 \mathrm{~cm}$ & 82 sztuki \\
\hline & & żwir jasny - $10 \mathrm{~m}^{2}$ & - & $0,5 \mathrm{~m}^{3}$ \\
\hline & & tłuczeń & $1-63 \mathrm{~mm}$ & $1,5 \mathrm{~m}^{3}$ \\
\hline
\end{tabular}

Źródło: P.P. Szumigała na podstawie ANDRZEJEWSKA (2006).

Source: P.P. Szumigała on the basis of ANDRZEJEWSKA (2006).

obecnie został nieznacznie powiększony w kierunku północno-zachodnim. Przeprowadzone w pracy analizy wskazały na niski standard zagospodarowania parku oraz wykazały i uzasadniły potrzebę jego modernizacji podyktowaną dużą, zróżnicowaną wiekowo liczbą użytkowników tego terenu (ryc. 5, fot. 5).

\section{WYNIKI I DYSKUSJA}

Prezentowane projekty zagospodarowania parków A. Wodziczki i W. Czarneckiego wskazują, że należy dołożyć wszelkich starań, aby utrzymać oba parki w jak najlepszej kondycj krajobrazowej i funkcjonalnej. O ile modernizacji poddano park Wodziczki, o tyle trzeba wykonać liczne prace modernizujące park Czarneckiego, zwłaszcza podjąć wiele inwestycji związanych z naprawą i wymianą nawierzchni, małej architektury i szaty roślinnej oraz aktualizacją programu użytkowego.

W trzech zaprezentowanych pracach magisterskich dotyczących parku A. Wodziczki (MrowiŃskI 2006, DembsKa 2007, KowalsKa 2012) określono konieczność rewaloryzacji parku, a szczególnie warstwy roślinnej. Przewidziano wiele nowych nasadzeń (tab. 1).

W opracowaniach dotyczących parku W. Czarneckiego (ANDRZejewsKa 2006, KorZuchowsKa 2016) istotnym elementem było wskazanie na konieczność wymiany nawierzchni na drogach parkowych (tab. 2) oraz przeprowadzenie ankiety społecznej, na podstawie której ustalono profil wiekowy użytkowników $\mathrm{i}$ ich oczekiwania związane $z$ funkcją parku. $Z$ ankiety wynika, że najliczniejszą grupą wiekową są osoby młode, w wieku 19-35 lat, a najmniej liczną osoby nastoletnie - 14-18 lat oraz osoby starsze - powyżej 50. roku życia. Do najczęstszych oczekiwań osób ankietowanych należą: poprawa oświetlenia, budowa fontanny i wybiegów dla psów.

\section{PODSUMOWANIE}

Analiza użytkowania wybranych parków oraz przegląd wyników aktualnych opracowań studialno-projektowych wskazują na pilną potrzebę zmiany sposobów zagospodarowania parków i dostosowania ich do potrzeb współczesnego użytkownika. Konieczne jest podjęcie wielu starań, $w$ tym finansowych, aby zapewnić jak najlepszą pielęgnację tych terenów. Należy także, korzystając $z$ wielu współczesnych metod kształtowania przestrzeni i architektury krajobrazu, dostosować przestrzeń publiczną do potrzeb współczesnych mieszkańców miast.

W koncepcjach dotyczących parków Adama Wodziczki i Władysława Czarneckiego zastosowano zasady estetyzacji, modernizacji i rewaloryzacji. Tworzą one podstawy programów działań inwestycyjnych na rzecz zachowania wartości kulturowych dwóch omawianych fragmentów krajobrazu miejskiego, utworzonych dla zachowania w pamięci i uhonorowania wybitnych i zasłużonych dla miasta Poznania Profesorów. Zaprezentowane wybrane rozwiązania przestrzenne mają na celu poprawę estetyki, kondycji roślinności oraz funkcjonalności parków, wpisując się w nurt współcześnie projektowanych obszarów rekreacji.

\section{LITERATURA}

Andrzejewska J. (2006): Projekt zagospodarowania Parku Władysława Czarneckiego oraz Parku przy ul. Serbskiej - Księcia Mieszka I w Poznaniu. Praca magisterska wykonana w Katedrze Terenów Zieleni Akademii Rolniczej im. A. Cieszkowskiego w Poznaniu, pod kierunkiem dr. hab. Piotra Urbańskiego, prof. nadzw. - materiał niepublikowany.

CZARneCKI W. (1961): Planowanie miast i osiedli. T. 3. PWN, Warszawa. 
DembsKa A. (2007): Koncepcja zagospodarowania zielenią i architekturą części obszaru Parku imienia Adama Wodziczki w Poznaniu. Praca magisterska wykonana w Katedrze Terenów Zieleni i Architektury Krajobrazu Uniwersytetu Przyrodniczego w Poznaniu, pod kierunkiem prof. dr. hab. Zbigniewa Habera - materiał niepublikowany.

Kodym-KozaczKo G. (2011): Poznański Ring w przestrzeni miasta. Krótka nauka urbanistyczna według obyczaju europejskiego. Odkryj Dzielnicę Zamkową. Wydawnictwo Miejskie Poznania, Poznań: 19-31.

KowalsKa A. (2012): Projekt rewaloryzacji Parku im. Adama Wodziczki w Poznaniu. Praca magisterska wykonana w Katedrze Terenów Zieleni i Architektury Krajobrazu Uniwersytetu Przyrodniczego w Poznaniu, pod kierunkiem dr. hab. Piotra Urbańskiego - materiał niepublikowany.

KorzuchowsKa M. (2016): Koncepcja modernizacji Parku Czarneckiego w Poznaniu. Praca magisterska wykonana w Katedrze Terenów Zieleni i Ar- chitektury Krajobrazu Uniwersytetu Przyrodniczego w Poznaniu, pod kierunkiem dr inż. Marii Chojnackiej - materiał niepublikowany.

ŁUKASIEWICZ A. (1982): Kryteria prawidłowego rozwoju terenów zieleni w aglomeracjach miejskich na przykładzie miasta Poznania. Wydawnictwo Naukowe UAM, Poznań.

Mrowiński Ł. (2006): Projekt estetyzacji Parku Adama Wodziczki i Parku miejskiego przy ul. Północnej w Poznaniu. Praca magisterska wykonana w Katedrze Terenów Zieleni Akademii Rolniczej im. A. Cieszkowskiego w Poznaniu, pod kierunkiem dr. hab. Piotra Urbańskiego, prof. nadzw. materiał niepublikowany.

For citation: Urbański P., Szumigata P.P., Tomczak P., Sosnowska S., Szumigaza K. (2018): Miejskie parki imienia Adama Wodziczki i Władysława Czarneckiego w Poznaniu. Steciana 22, 4: 133-142. doi: 10.12657/steciana.022.016 